\title{
The Level of Water Supply and its Effect on the Growth of Plants and Yields Patchouli (Pogostemon Cablin, Benth.)
}

\author{
Nasruddin $^{1}$, Erwin Masrul Harahap ${ }^{2}$, Chairani Hanum ${ }^{2}$ and Luthfi Azis Mahmud Siregar ${ }^{2}$ \\ \{nasruddin.fp@unimal.ac.id\} \\ ${ }^{1}$ Doctoral Program of Agricultural Sciences, Faculty of Agriculture, Universitas Sumatera Utara, \\ Jl. Dr. A. Sofyan No. 3 Padang Bulan, Medan 20155, Indonesia \\ ${ }^{2}$ Program Study of Agrotechnology, Faculty of Agriculture, Universitas Sumatera Utara, \\ J1. Dr. A. Sofyan No. 3 Padang Bulan, Medan 20155, Indonesia
}

\begin{abstract}
Patchouli is a plant of essential oils cultivated dry land without any irrigation except rainfall only. The low amount of water in cultivation is a common constraint and hampers growth and patchouli yield. This study aims to obtain the appropriate level of water content on patchouli cultivation in rain-fed and how it impacts on growth and results. Implemented in Reuleut Timu Village Muara Batu District, North Aceh District from June to December 2015. Using randomized block design a repeated of 9 (nine) times with the following treatments: $\mathrm{K}_{1}=$ water supply $100 \%$ of field capacity, $\mathrm{K}_{2}=$ water supply $75 \%$ field capacity, $\mathrm{K}_{3}=$ water supply $50 \%$ field capacity $\mathrm{K}_{4}=$ water supply $25 \%$ field capacity. The results of this study indicate that the water content in the field capacity showed very significant difference to the patchouli leaf area. 75$100 \%$ moisture content results in better oil production and growth, while the highest patchouli alcohol content is achieved at 50\% moisture content. The lower the water content given, the more negatively affect the growth and yield of patchouli plants.
\end{abstract}

Keywords: Patchouli Alcohol, Moisture Content, Water Shortage, Field Capacity.

\section{Introduction}

Patchouli (Pogostemon cablin, Benth) is an essential oil producing plant originating from the subtropical of the Himalayas, Southeast Asia and the Far East and is widely cultivated in Indonesia, China, Malaysia, and Brazil [1]. Aceh is the best quality patchouli oil producer and has become Indonesia's largest supplier of patchouli oil in the international market $[2,3]$.

Grows well in height up to $1,200 \mathrm{~m}$ above sea level. Patchouli cultivation is very suitable to be done in areas with sufficient rainfall, especially in the highlands. Patchouli cultivation in the lowlands is often lack of water and irrigation is needed to fulfill it. Plants with water shortages generally produce low growth and production and can have an impact on cultivar failure. The need for water or rainfall of patchouli plants to grow and produce well ranges from 2,500 - 3,000 mm per year [1]. Compared to the average annual rainfall in North Aceh of $1,478 \mathrm{~mm} /$ year, there will be a shortage or inadequate water demand so that patchouli plants 
are potentially in a state of water shortage. Generally patchouli cultivated on land with irrigation from rainfall only. Patchouli plants have shallow rooting so less resistant to drought.

Such rooting morphological characteristics cause patchouli very easily to experience water shortages resulting in disruption of growth and production. Such root morphological characteristics and low rainfall and uneven fall in each month to make the patchouli cultivation of the place into the category does not fit.

In general, the average yield of leaves (terna dry) on patchouli plants is about 15 tons / ha or about $290-375 \mathrm{~kg} / \mathrm{ha}$ of patchouli oil with $32-33 \%$ patchouli alcohol content.

To date, information on how moisture still in the patchouli plant tolerance to grow and produce well unknown. To know the level of moisture which is good for growth and results achieved, and then conducted research with the treatment the granting of different moisture on plant patchouli. This study aims to obtain the appropriate level of water content on patchouli cultivation in rain-fed and how it impacts on growth and results.

\section{Materials and Methods}

Research was conducted in Reuleut Timu village, sub-district of Muara Batu in North Aceh Regency height $\pm 8 \mathrm{~m}$ above sea level (asl). Implemented from June to December 2015 . The material used is patchouli Pogostemon cablin Benth, cow manure, polybag, urea fertilizer, SP-36 and $\mathrm{KCl}, 3 \mathrm{G}$, fungicide and insecticide.

Tools used include oven, digital scales, leaf area meter. Implemented in a plastic housing using a non factorial randomized block design. The treatment given is the level of water delivery, which consists of 4 levels ie : $\mathrm{K}_{1}=$ water supply $100 \%$ field capacity, $\mathrm{K}_{2}=$ water supply $75 \%$ field capacity, $\mathrm{K}_{3}=$ water supply $50 \%$ and $\mathrm{K}_{4}=$ water supply $25 \%$ field capacity, repeated 9 times.

Cuttings for seedlings taken from branches that are young but have wood with a length of $15-20 \mathrm{~cm}$. The topsoil mixed with manure as a seedbed medium is inserted into the polybag and arranged at a distance of $20 \mathrm{~cm} \times 20 \mathrm{~cm}$.

Each polybag planted with a patchouli seedlings and given a shade of paranet. Cuttings seedlings maintained until one month or have had shoots and then moved into large polybag $(60 \mathrm{~kg})$. The planting medium at 60 kilograms of size polybag is the soil top soil that was already crushed. The soil top soil mixed with cow manure with a comparison of 2:1.

The patchouli seedlings were planted into polybags of $60 \mathrm{~kg}$ and arranged with $60 \mathrm{~cm} \mathrm{x} 40$ $\mathrm{cm}$ plant spacing in each randomized trial plot. Planting is done by making the planting hole according to the size of polybag seedlings, then put the seeds along with the media seedlings. Each large polybag planted with one seed of patchouli plant.

To ensure perfect growth occurs watering, fertilizing, weeding and plant pests eradication. If there are plants that die or grow imperfectly done embroidery.

Provision of water treatment is done after the plant are thirty days after transplanting (dat) according to the percentage of field capacity, and carried up to the age of patchouli six months. To ensure the level of groundwater content, each treatment unit measured its water content with a tensiometer.

Weeding is done by unplugging the plant pest (weed) on each poly bag to suit your needs. For tackling pest plant disease is done by spraying with insecticides and fungicides. Spraying plant disease pests are done according to your needs.

Observation on the growth and yield were performed on plant height, leaf number, leaf area, root length, oil production, patchouli alcohol (PA) content at 180 days after planting. The 
data were analyzed by anova and futher test the least significant difference (LSD) on levels $5 \%$.

\section{Results and Discussion}

The result of variance analysis showed significant difference to leaf area due to treatment of water content. The highest leaf area was achieved at the $\mathrm{K}_{1}$ treatment stage with $100 \%$ moisture content of $33.99 \mathrm{~cm}^{2}$, followed by $\mathrm{K}_{2} 25.99 \mathrm{~cm}^{2}, \mathrm{~K}_{3} 22.47 \mathrm{~cm}^{2}$ and $\mathrm{K}_{4} 21.70 \mathrm{~cm}^{2}$.

The giving of water treatment does not show a significant difference against the high number of plants, leaves and the root length. Although not a significant difference, the greatest plant height indicated by the extent of awarding $100 \%$ of water levels $\left(\mathrm{K}_{1}\right)$ of 45.07 $\mathrm{cm}$ followed by $\mathrm{K}_{2}$ of $44.85 \mathrm{~cm}, \mathrm{~K}_{4}$ of $39.80 \mathrm{~cm}$, and $\mathrm{K}_{3}$ of $38.80 \mathrm{~cm}$. The same thing happened against the parameters of the length of the root, where the root is the longest in the show by $\mathrm{K}_{1}$ of $26.91 \mathrm{~cm}$ followed by $\mathrm{K}_{4}$ of $26.19 \mathrm{~cm}, \mathrm{~K}_{2}$ and $\mathrm{K}_{3}$ amounting to $25.89 \mathrm{~cm}$ by $22.00 \mathrm{~cm}$, while the number of leaves in the show's highest level of treatment by $\mathrm{K}_{2}$ of 51.13 strands followed by $\mathrm{K}_{1}$ of 50.80 strands, $\mathrm{K}_{4}$ of $45.00 \mathrm{~K}_{3}$ of the strands and strands of 40.79 (Figure 1).

Treatment of water content is lower the negative effect on the growth of patchouli plants is the decrease in plant height, leaf area, the number of leaves, and the length of the roots of patchouli plants. Water content of $\mathrm{K}_{1}$ treatment level on the parameters of plant height was better by $0.48 \%$ of $\mathrm{K}_{2}, 13.91 \%$ of $\mathrm{K}_{3}$ and $11.70 \%$ of $\mathrm{K}_{4}$. On the parameters of the large decrease of leaf number seen at $\mathrm{K}_{3}$ and $\mathrm{K}_{4}$ that is equal to $20.30 \%$ and $11.99 \%$ compared with $\mathrm{K}_{1}$, while at $\mathrm{K}_{2}$ level able to increase the number of patchouli leaves by $0.65 \%$. Patchouli plant root length parameter which is the organ of water absorption and nutrients produces the highest root length on treatment water content level $\mathrm{K}_{1}$ and larger $3.79 \%$ from $\mathrm{K}_{2}, 18.24 \%$ from $\mathrm{K}_{3}$ and $2.67 \%$ from $\mathrm{K}_{4}$. Against the broad parameters of leaves, granting the lower water levels cause a decrease in the broad leaves are getting bigger. When compared to $\mathrm{K}_{1}$ treatment stage, the decrease of leaf area occurred at $\mathrm{K}_{2}$ is $23.55 \%$, at $\mathrm{K}_{3}$ level of $33.88 \%$ and $36.18 \%$ in the $\mathrm{K}_{4}$ level (Figure 1). The greater the water given the greater the effect on the increase of plant height growth, the number of leaves, the leaf area and the lenght of the patchouli plant roots, otherwise the smaller the water content given decrease the growth of patchouli plant.

The $100 \%$ water supply levels result in higher patchouli oil than other moisture content. This indicates that patchouli plants require a sufficient amount of water and are always available, but not excessive. At low water availability levels, the energy allocated for growth will decrease as a result of the amount of energy required to absorb water so that the respiration rate is greater than photosynthesis. Research results Wiroatmodjo, et al. [4]; Kadir [3] indicates that low water levels decrease the number of branches and the number of patchouli leaves Effects Water deficiency in plants causes a decrease in plant height and leaf area [5], significantly reduced fresh and dried biomass yields with increasing water shortages [6]. The research of Amiri, et al. [7], water stress significantly affects plant growth decline, for example at plant height. Severe water shortages are more damaging than moderate water shortages [8]. Low moisture depresses significantly the expansion of cells and growth due to low turgor pressure.

Setting the osmotic turgor maintenance can allow cells to survive or to aid plant growth under severe drought conditions [9]. Water shortages inhibit shoot growth as indicated by decreased growth in plant height, number of root and number of leaves [10]. 

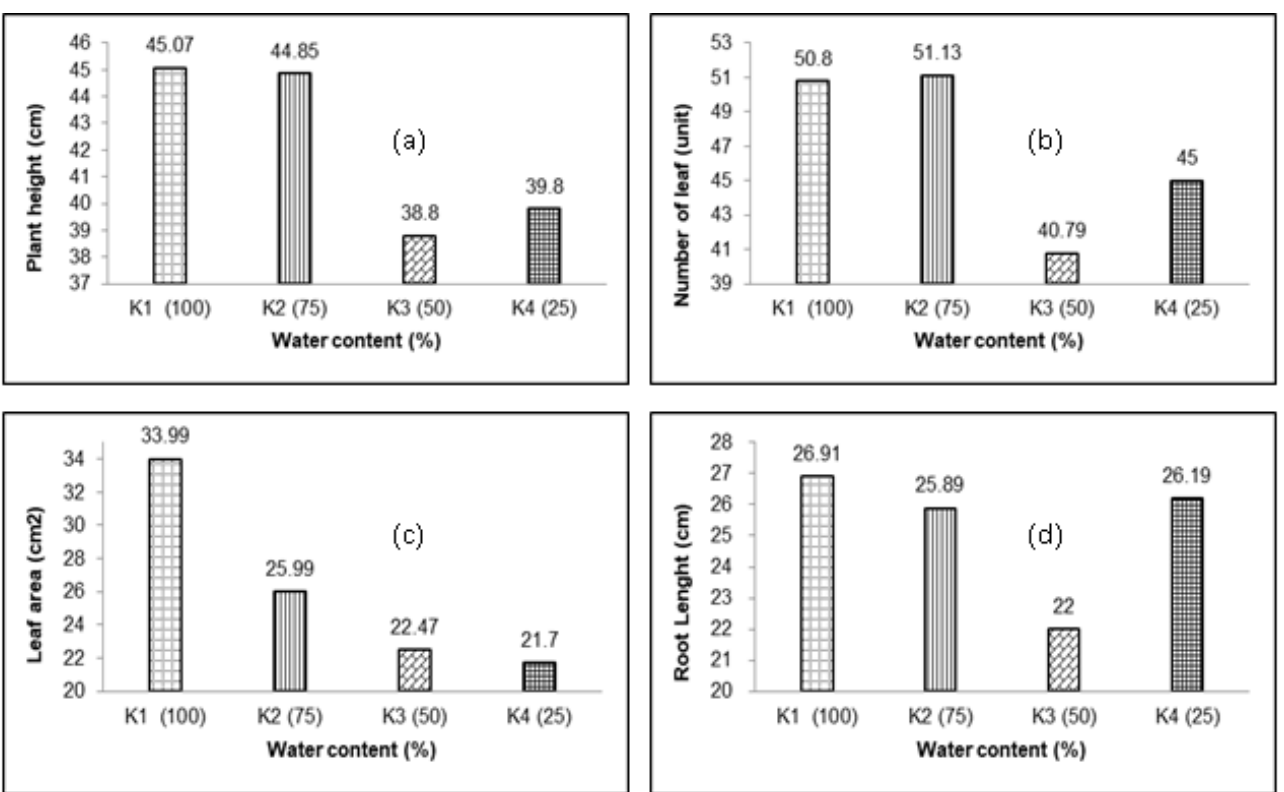

Figure 1. Patchouli growth on plant height parameters (a), number of leaves (b), leaf area (c) and root length (d) of patchouli plant.

In this research, plant patchouli has small leaves, the habitus is rather small and thick, reddish yellow green color somewhat because it is grown in the open. Patchouli plants grown in the open, less growth, smaller plants running, rather small and thick leaves, the leaves are yellowish and slightly red, it is because of the disruption of cell division which lowers growth and results, but higher oil levels [11,12]. Low water content affects all plant growth variables observed. Plants given adequate water (75-100\%) have a growing number of leaves, root biomass, plant height, and leaf area larger than the water supply of $25-50 \%$. The low input of water causes low biomass growth of leaves and leaf area. Low water input causes low leaf biomass growth and leaf area. The formation of leaves, roots and stems is significantly influenced by the water content given [13]. Whilst Manivannan, et al. [14] revealed that the decrease in plant height associated with a decrease in cell enlargement and leaf aging, under water deprivation conditions. Increased water supply results in increased plant height and number of leaves, and low water delivery drastically decreases the number of leaves and leaf area $[15,16]$.

The low amount of patchouli leaves in the treatment of more severe water shortages caused by the existence of plants has waived its leaves to reduce excessive evaporation. In addition, research conditions under plastic house higher temperatures followed by the low humidity makes faster portion dismissed the patchouli leaves, especially old leaves. The plant is more sensitive to water shortage more abort the leaves [17]. Plant growth can be inhibited by low water potential, this can be shown in the growth of leaves and stems [18]

Height of plants under heavy water shortage is lower than in moderate water shortages, this may be due to more concentrated plants prolonging the roots to obtain more water from deeper sources, less root inhibition than upper canopy growth [19,20]. Some roots continue to lengthen to a low groundwater potential and reduce shoot growth (Kirnak, et al. [18]. A productive root system can provide benefits for spurring plant growth at an early stage of its 
growth and facilitating the rapid absorption of water lost by evaporation [21]. ). Increased root growth due to water stress occurs in sunflower as reported by Tahir, et al. [22] and plant Catharanthus roseus [23].

This study shows that patchouli plants can still continue the process of growth and development to water shortages at levels up to 25 percent, but in research Setiawan, et al. [24] the plant can still continue its life up to 20 percent groundwater content.

Treatment of water content resulted in the highest production of Patchouli oil at $\mathrm{K}_{1}$ (100\%) level of 4.91 gram followed by $\mathrm{K}_{3}(50 \%) 4.90$ gram, $\mathrm{K}_{2} 4.23$ gram and $\mathrm{K}_{4} 2.64$ gram (Figure 2a). In general, the greater the provision of water in patchouli plants produce oil is higherl, except in $K_{3}$ able to produce oil weight is almost equal to $K_{1}$. The treatment of the amount of water in decreased field capacity resulted in decreasing production of patchouli oil. Compared to $\mathrm{K}_{1}$ treatment level, water supply in $\mathrm{K}_{2}$ field capacity causes a decrease of patchouli oil production by $13.85 \%, \mathrm{~K}_{3}$ decreases yield of $0.20 \%$ and $\mathrm{K}_{4}$ decreases yield by $46.23 \%$.
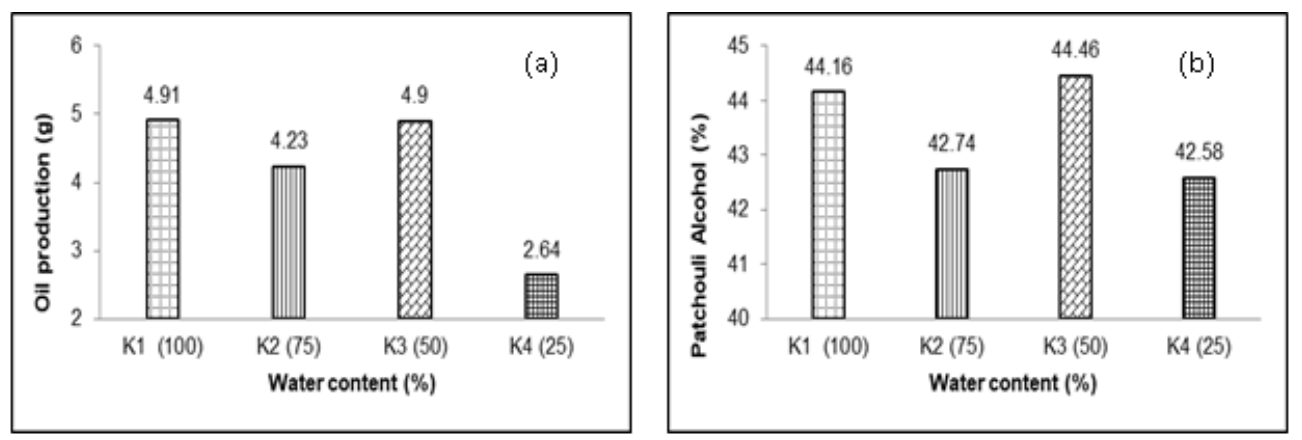

Figure 2. A comparison of patchouli oil production (a) and patchouli alcohol content (b) patchouli plants due to the treatment of moisture content.

Treatment of water content resulted in differences in patchouli alcohol content of patchouli oil (Figure 2b). The highest patchouli alcohol content was demonstrated at water content in $50 \%\left(\mathrm{~K}_{3}\right)$ field capacity with patchouli alcohol content of $44.46 \%$ followed by $\mathrm{K}_{1}$ $44.16 \%\left(0.67 \%\right.$ lower than $\left.\mathrm{K}_{3}\right), \mathrm{K}_{2} 42.74 \%$ (3.87\% lower than $\mathrm{K}_{3}$ ) and $\mathrm{K}_{4} 42.58 \%(4.23 \%$ lower than $\mathrm{K}_{3}$ ) (Figure 2).

The decline in crop production results related to a decrease in the number of leaves and interference in the process of cell division [25]. Water stress reduces fresh weight and dry weight of plants, but the more severe the water shortage will increase the essential oil content than light water stress [26]. Differently expressed in plants Matricaria chamomila the greater the water shortage that is given further lower the high content of essential oils and plants. A decrease in the content of essential oil may be caused by the presence of interference in photosynthesis, carbohydrate and production at the time of formation of water shortage, the formation of secondary metabolism due to depressed plant growth [8]. Lack of water pressed essential oil production instead of sufficiency of water gives higher oil production [27]. 


\section{Conclusion}

Giving different moisture content of patchouli plants has a very significant effect on leaf area. Although there was no significant difference in plant height, leaf number and root length, water content with $100 \%$ and $75 \%$ field capacity resulted in better growth and production compared to water content of $25 \%$ and $50 \%$ of field capacity. $100 \%$ and $50 \%$ moisture content resulted in the highest production of patchouli oil, while the highest patchouli alcohol content was achieved at $50 \%$.

\section{References}

[1] A. Yahya and R. M. Yunus, "Influence of Sample Preparation and Extraction Time on Chemical Composition od Steam Distillation Patchouli Oil," in Malaysian Technical Universities Conference on Engineering \& Technology 2012, MUCET 2012, 2013, pp. 1-6.

[2] M. K. Swamy and U. R. Sinniah, "Patchouli (Pogostemon cablin, Benth.): Botany, agrotechnology and biothechnological aspects," Industrial Crops and Products, vol. 87, pp. 161-176, 2016.

[3] A. Kadir, "Identifikasi klon harapan tanaman nilam toleran cekaman kekeringan berdasarkan kadar proline dan karakter morfologi dan fisiologi," Jurnal Agrisistem, vol. 7, 2011.

[4] J. Wiroatmodjo, I. H. Utomo, and E. Sulistyono, "Pengaruh tingkat pemberian air, pemupukan dan kerapatan gulma B. alata terhadap pertumbuhan dan berat kering nilam " Bul. Agron., vol. 19, pp. 80-82, 1990.

[5] M. B. Khan, N. Hussain, and M. Iqbal, "Effect of water stress on growth and yield components of maize variety YHS 202," Journal of Research (Science), vol. 12, pp. 15-18, 2001.

[6] T. J. Zhao, S. Sun, Y. Liu, J. M. Liu, Q. Liu, Y. B. Yan, et al., "Regulating the drought-responsive element (DRE)-mediated signaling pathway by synergic functions of trans-active and trans-inactive DRE binding factors in Brassica napus," $J$ Biol Chem, vol. 281, pp. 10752-9, Apr 212006.

[7] R. Amiri, A. Nikbakht, M. Rahimmalek, and H. Hosseini, "Variation in the Essential Oil Composition, Antioxidant Capacity, and Physiological Characteristics of Pelargonium graveolens L. Inoculated with Two Species of Mycorrhizal Fungi Under Water Deficit Conditions," Journal of Plant Growth Regulation, pp. 1-14, 2017.

[8] Moinuddin, M. M. A. Khan, and M. Naeem, "Drought stress effects on medical and aromatic plants and the possible stress amelioration by mineral nutrition," Medicinal and Aromatic Plant Science and Biotechnology, vol. 6, pp. 69-83, 2012.

[9] H.-b. Shao, L.-y. Chu, M.-a. Shao, C. A. Jaleel, and M. Hong-mei, "Higher plant antioxidants and redox signaling under environmental stresses," Comptes rendus biologies, vol. 331, pp. 433-441, 2008.

[10] E. S. Rahayu, E. Guhardja, and S. Ilyas, "Polietilena glikol (PEG) dalam media in vitro menyebabkan kondisi cekaman yang menghambat tunas kacang tanah (Arachis hypogaea L.)," Berk. Penel. Hayati, vol. 11, pp. 39-48, 2005.

[11] M. Hussain, M. A. Malik, and M. Farooq, "Improving drought tolerance by exogenous application of glycinebetaine and salicylic acid in sunflower," Journal Agronomy \& Crop Science, vol. 194, pp. 193-199, 2008.

[12] R. Rosman, Setyono, and H. Suhaeni, "Pengaruh naungan dan pupuk fosfor terhadap pertumbuhan dan produksi nilam (Pogostemon cablin, Benth). ," Buletin Tro, vol. XV, pp. 10-16, 2004. 
[13] C. Ky-Dembele, J. Bayala, P. Savadogo, M. Tigabu, P. C. Oden, and I. J. Boussim, "Comparison of growth responses of Khaya senegalensis seedlings and stcklings to four irrigation regimes," Silva Fennica, vol. 44, pp. 787-798, 2010.

[14] P. Manivannan, C. A. Jaleel, R. Somasundaram, and R. Panneerselvam, "Osmoregulation and antioxidant metabolism in drought-stressed Helianthus annuus under triadimefon drenching," Comptes Rendus Biologies, vol. 331, pp. 418-425, 2008.

[15] F. Wu, W. Bao, F. Li, and N. Wu, "Effects of drought stress and N supply on the growth biomass partitioning and water-use effeciency of Sophora davidii seedlings," Environmental and Experimental Botany, vol. 63, pp. 248-255, 2008.

[16] V. Taweesak, T. Lee Abdullah, S. A. Hassan, N. H. Kamarulzaman, and W. A. Wan Yusoff, "Growth and flowering responses of cut chrysanthemum grown under restricted root volume to irrigation frequency," The Scientific World Journal, vol. 2014, 2014.

[17] F. M. DaMatta, "Exploring drought tolerance in coffee: a physiological approach with some insights for plant breeding," Brazilian Journal of Plant Physiology, vol. 16, pp. 1-6, 2004.

[18] H. Kirnak, C. Kaya, I. Tas, and D. Higgs, "The influence of water deficit on vegetative growth, physiology, fruit yield and quality in eggplants," Bulg. J. Plant Physiol, vol. 27, pp. 34-46, 2001.

[19] H. Kage, M. Kochler, and H. Stützel, "Root growth and dry matter partitioning of cauliflower under drought stress conditions: measurement and simulation," European Journal of Agronomy, vol. 20, pp. 379-394, 2004.

[20] A. M. A. Hassanein, "Effects of irrigation and method of fertilization on growth and flowering responses of potted Chrysanthenum," Journal of Horticultural Science \& Ornamental Plants, vol. 7, pp. 80-86, 2015.

[21] C. Johansen, B. Baldev, J. Brouwer, W. Erskine, W. Jermyn, L. Li-Juan, et al., "Biotic and abiotic stresses constraining productivity of cool season food legumes in Asia, Africa and Oceania," in Expanding the production and use of cool season food legumes, ed: Springer, 1994, pp. 175-194.

[22] M. H. N. Tahir, M. Imran, and M. K. Hussain, "Evaluation of sunflower (Helianthus annuus L.) inbred lines for drought tolerance," International Journal of Agriculture and Biology, vol. 3, pp. 398-400, 2002.

[23] C. A. Jaleel, P. Manivannan, A. Wahid, M. Farooq, H. J. Al-Juburi, R. Somasundaram, et al., "Drought stress in plants: a review on morphological characteristics and pigments composition," Int J Agric Biol, vol. 11, pp. 100-105, 2009.

[24] Setiawan, Tohari, and D. Shiddieq, "Pengaruh cekaman kurang air terhadap beberapa karakter fisiologis tanaman nilam (Pogostemon cablin, Benth)," Littri, vol. 19, pp. 108-116, 2013.

[25] P. A. Sikuku, G. W. Netondo, D. M. Musyimi, and J. C. Onyango, "Effects of water deficit on days to maturity and yield of three nerica rainfed rice varieties," ARPN Journal of Agricultural and Biological Science, vol. 5, pp. 1-9, 2010.

[26] A. Chauhan, R. S. Verma, and R. C. Padalia, "Influence of biotic and abiotic factors on yield and quality of medical and aromatic plants," in Climate change effect on crop productivity, R. S. Sengar and K. Sengar, Eds., ed Boca Raton: CRC Press Taylor \& Francis Group, 2015. 
[27] K. Razmjoo, P. Heydarizadeh, and M. R. Sabzalian, "Effect of salinity and drought stresses on growth parameters and essential oil content of Matricaria chamomile," Int. J. Agric. Biol, vol. 10, pp. 451-454, 2008. 